\title{
Article
}

\section{Legitimation and Strategic Maneuvering in the Polftical Field}

leţcu-Fairclough, Isabela

Available at http://clok.uclan.ac.uk/3418/

leţcu-Fairclough, Isabela ORCID: 0000-0001-6718-2636 (2008) Legitimation and Strategic Maneuvering in the Political Field. Argumentation, 22 (3). pp. 399-417. ISSN 0920-427X

It is advisable to refer to the publisher's version if you intend to cite from the work. http://dx.doi.org/10.1007/s10503-008-9088-9

For more information about UCLan's research in this area go to

http://www.uclan.ac.uk/researchgroups/ and search for < name of research Group>.

For information about Research generally at UCLan please go to http://www.uclan.ac.uk/research/

All outputs in CLoK are protected by Intellectual Property Rights law, including Copyright law. Copyright, IPR and Moral Rights for the works on this site are retained by the individual authors and/or other copyright owners. Terms and conditions for use of this material are defined in the policies page.

\section{CLoK}

Central Lancashire online Knowledge www.clok.uclan.ac.uk

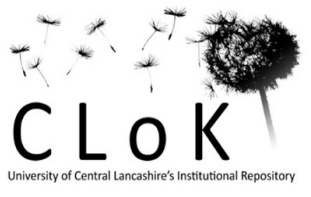


Isabela Ieţcu-Fairclough (University of Bucharest)

\title{
Legitimation and strategic maneuvering in the political field
}

\begin{abstract}
This article combines a pragma-dialectical conception of argumentation, a sociological conception of legitimacy and a sociological theory of the political field. In particular, it draws on the theorization of the political field developed by Pierre Bourdieu and tries to determine what new insights into the concept of strategic maneuvering might be offered by a sociological analysis of the political field. I analyse a speech made by the President of Romania, Traian Băsescu, following his suspension by Parliament in April 2007. I suggest that the argument developed in this speech can be regarded as an example of adjudication and I discuss its specificity as an adjudication in the political field in an electoral campaign. I also try to relate legitimation as political strategy to strategic maneuvering oriented to meeting the contradictory demands of the political field, which I see - following Bourdieu - as involving a double political game, a game of democratic representation and a game of power.
\end{abstract}

KEYWORDS: adjudication, Bourdieu, legitimacy, legitimation, political field, pragma-dialectics, public justification, strategic maneuvering, Traian Băsescu

In this article I am trying to bring together a pragma-dialectical conception of argumentation, a sociological conception of legitimacy, as well as a sociological theory of the political field. I will draw on the pragma-dialectical theory of argumentation developed by van Eemeren and Grootendorst (1992, 2004) and particularly on the concept of strategic maneuvering (van Eemeren and Houtlosser 2002), as well as on approaches to legitimacy by philosophers and sociologists (Habermas 1976, 1984, Beetham 1991). In particular, I will draw on the theorization of the political field developed by Bourdieu (1991). Using insights from these theoretical sources, I will try to analyze a political speech and relate argument evaluation issues to the characteristics of the political field and to a particular view of legitimacy.

\section{Approaches to 'legitimation' and 'legitimacy'}

In social and political theory, the concepts of 'legitimacy' and 'legitimation' are generally defined in terms of concepts of argumentation, giving or having reasons, and justification. A standard view is that 'the measure of legitimacy of regimes is fundamentally tied to discursive justifiability' (D’Agostino 2007) and political philosophers have proposed different conceptions of public justifiability, hence different conceptions of legitimacy. 
For most contemporary theorists, to say that power is legitimate is to make either a descriptive or a normative judgment. Weber, for instance, understood legitimate authority in the descriptive sense: power is legitimate if people believe it to be legitimate. Other theorists insist on 'good reasons': there must be some 'reasonable consensus' (Rawls), or 'rationally motivated agreement' or 'rational consensus' (Habermas). On a descriptive approach, to say that a regime is legitimate is to make a report on people's beliefs. On a normative view, it is to pass a (moral) judgment on that regime. On the normative approach, legitimacy is tied to a process of public justification. In turn, public justification is tied to 'reasonableness', i.e. it is understood as 'reasonableness from every point of view'. It thus becomes possible to say that 'no regime is legitimate unless it is reasonable from every individual's point of view' (D'Agostino 2007). This strong requirement is then read either as referring to actual individuals' beliefs or to what individuals would believe if they were better informed, or placed in some other 'ideal' counterfactual situation. ${ }^{1}$

There are at least two major normative views: Habermas's and Rawls's. According to Habermas, legitimacy designates 'the worthiness of a political order to be recognized', or, in other words, that 'there are good arguments for a political order to be recognized as right and just' (Habermas 1996: 248). In modernity, when 'ultimate' grounds are no longer plausible, legitimacy becomes procedural. It is now the formal procedures and conditions on possible consensus formation that possess legitimizing force. A normative claim becomes legitimate if it is the object of an 'agreement that comes to pass among all parties, as free and equal', at the end of a process of deliberation that is free from deception and the distorting constraints of power, and thus embodies the general interest. Similarly, Rawls (1993) proposes a view of legitimate social arrangements based on a notion of 'reasonable consensus'. The basic principle of reasonableness asserts that reasonable persons will propose to other persons terms of cooperation that are fair only on condition that these terms can be justified to those others on the basis of premises that they can reasonably accept (Christiano 2004). ${ }^{2}$

Beetham's (1991) sociological account of legitimacy is critical of both Weber's descriptive approach and of normative approaches that impose too strong and a-historical constraints on judgments of legitimacy. For the latter, Beetham argues, power is legitimate when the rules that govern it are justifiable according to rationally defensible moral principles and these embody a universalizing claim: it is not the principles that happen to pertain in a given society at a given time that are at issue here, but those that any rational person, upon considered and unbiased reflection, would have to agree to (Beetham 1991: 4). The disadvantage of this view, Beetham shows, is that it divorces judgements of legitimacy from context and history. Instead, he suggests a view of legitimacy-in-context, based on the following crucial claim: 'A given power relationship is not legitimate because people believe in its legitimacy, but because it can be justified in terms of their beliefs' (Beetham 1991:11). Consequently, power is legitimate to the extent that:

(a) it conforms to established rules (level of rules);

(b) the rules can be justified by reference to beliefs shared by both dominant and subordinate (level of justifications grounded in beliefs);

(c) there is evidence of consent by the subordinate to the particular power relation (level of action) (Beetham 1991:16). 
I am going to adopt Beetham's approach in my analysis of the speech made by the President of Romania, Traian Băsescu, following his suspension by Parliament in April 2007. I will try to show how self-legitimation and delegitimation of political opponents and of associated standpoints proceeds by drawing on the three levels identified by Beetham, and by invoking various types of 'rules': legal rules, democratic rules, as well as by drawing on different sets of beliefs and norms allegedly shared by the audience. I will try to address three particular issues:

(a) In the spirit of recent research in pragma-dialectics, I will look at the text as (partly) an adjudication, and discuss its specificity as an adjudication in the political field in an electoral campaign.

(b) Drawing on the sociological theory of Pierre Bourdieu (1991), I will place this speech within the broadly-defined rules of the political field, in order to explore the way in which the particular rules or logic of the political field might bear upon judgments of reasonableness.

(c) Finally, in my concluding section, I will relate legitimation as political strategy to strategic maneuvering oriented to meeting the contradictory demands of the social and political fields.

\section{Legitimacy as a multi-level concept. Different 'levels' of legitimacy in the 'legal' yet 'illegitimate' suspension of the President of Romania.}

Parliament suspended the President of Romania on the $20^{\text {th }}$ of April 2007 and called the referendum on the grounds that Băsescu, who had always described himself as an active president, had exceeded his legitimate constitutional powers. In 2004, Băsescu became president because he promised to put a stop to corruption and the attempt to impeach him can be taken as a concerted reaction to his anti-corruption campaign. In Parliament, 322 MPs voted in favour of the suspension and 108 against. A month later, however, in the referendum (on May 19, 2007), the Romanian electorate rejected Parliament's attempt to impeach the President. Approximately $75 \%$ of those who went to the polls voted against impeachment and approximately $25 \%$ voted in favour.

One of the characteristics of the one-month campaign between the suspension and the referendum was an explicit focus on legitimacy. Parliament asserted its own legitimacy, as elected representative of the people, and the legitimacy of the Constitution, which Băsescu had allegedly violated. Băsescu, media commentators and members of the public denied the legitimacy of the Parliament, by pointing out that the majority of the population disapproved of the suspension and the impeachment. More interestingly still, they argued that, although Parliament is a democratically elected institution in principle, it was not really legitimate at all, given that its members had not been elected individually, by uninominal vote, but on party lists.

These various views can be translated into Beetham's three-level framework. For instance, Băsescu's position was illegitimate, according to some people, because it violated the limited prerogatives granted to the President by the Romanian Constitution, i.e. according to the first level, of 'rules'. On the other hand, for all of those who questioned the Constitution itself and the laws which defined the legal powers of the President and Parliament, Băsescu was not illegitimate. Or, again, for a great many people, Băsescu seemed to be perfectly legitimate in his actions from the 
perspective of the rules of the democratic game (first level) and also from the perspective of most people's shared beliefs and normative expectations (second level). Equally, we can say he was legitimate from the point of view of the expressed consent of a significant proportion of the population. The position of his opponents (the 322 MPs) was legitimate from the point of view of the level of rules (first level), if by rules we understand the Constitution, and illegitimate from the same perspective if by rules we understand a democratic system in which MPs are expected to represent the will of the majority. It was also illegitimate from the point of view of most people's shared beliefs and norms (second level), and their expressed consent (third level).

\section{The institutional context: adjudication as activity type}

I am going to look at the text of Băsescu's suspension speech as an instance of adjudication in the political field. In so doing, I am drawing on recent developments in pragma-dialectics which suggest that fallacy judgments may depend on various contextual factors, and may not be produced simply by comparing the argumentation in question with the set of rules that define critical discussion. One dimension or aspect of the context is the institutional context, and more specifically, the activity type that the arguers are engaged in, seen as a culturally established and codified practice, with a more or less fixed format. In various articles, van Eemeren (2006) and van Eemeren and Houtlosser $(2005,2006)$ compare the argumentative activity types of adjudication, mediation and negotiation and argue that the institutional circumstances inherent in a specific activity type determine the dialectical preconditions for strategic maneuvering. They define adjudication as an activity type that aims for the termination of a dispute by a third party, rather than the resolution of a difference of opinion by the parties themselves. In adjudication, the parties readjust their roles from trying to convince each other to trying to convince the presumably neutral, impartial adjudicator.

As an activity type, the interaction between Băsescu as protagonist and the audience seems to combine features of an argumentative discussion between two parties (Băsescu and his immediate public) with features of an adjudication, i.e. the President is presenting his case, trying to legitimize his position in front of the people as adjudicator, of which the particular assembly he is addressing seems to be a metonymical subset. This is not prototypical adjudication and I will identify features of it which make it atypical and which may be said to arise from the properties of the political field. However, my suggestion that the interaction can be regarded in these terms, as an adjudication, is supported by the fact that the people were in fact called upon to decide, through a referendum, on May 19, whether Băsescu was 'guilty' of the accusations brought against him; and especially that, in the speech in question, Băsescu does try to clear himself of the accusations and plead his case before the people.

In this speech, Băsescu is addressing an implicit difference of opinion among the electorate, between those who would vote Yes in the impeachment referendum and those who would vote No. There are several participants in this interaction: Băsescu as the main protagonist, the immediate, co-present public as antagonist and protagonist, the 322 MPs that voted against Băsescu as a represented protagonist. There are two publics. There is, on the one hand, an immediate public, who engages in interaction with Băsescu, and occasionally expresses agreement or voices some distinct standpoint of its own. There is also a more general, wider public, who is cast 
here in the role of a supposedly neutral adjudicator that eventually has to give a verdict. In addressing his immediate audience of supporters (an audience that does not really need to be persuaded), Băsescu is at the same time addressing the wider public, the electorate. In constructing and exploiting the consensus of views with his immediate public, he is actively constructing a wider consensus with parts of the electorate that might vote against him. He seems to address his immediate audience as a sort of metonymical subset of the Romanians at large and to attribute identical value commitments to these two publics. Nowhere is it apparent from his speech that amongst the wider audience there might be a significant proportion of voters who might choose to vote in favour of the impeachment.

Here is the text of the speech that Traian Băsescu made after his suspension by Parliament, in Constitution Square, in Bucharest, on April 22, 2007 (my translation). (The speech is in italics, to avoid confusion with my own comments):

"Welcome. It's good to be here with you. I want to thank you for sacrificing a Sunday to come here so that together we might reassert our confidence in democracy and in the rule of law. (...) I would like to begin by wishing a happy name day to all those men and women whose name is connected to Saint George. Tomorrow Saint George will also inaugurate the campaign for the referendum. Are we expected to fight a dragon? I think we are. It is that part of the state created during transition that will not accept that the time has come for Romania to become a modern state. One where institutions work for the citizens, wherever they might find themselves."

From the very beginning, Băsescu constructs an audience that shares his values, his alleged 'confidence in democracy' (he invokes these as helpful concessions for his case at the opening stage) and clearly places the discussion within the framework of a particular 'game' and set of 'rules': the democratic game, and not, for instance, the Constitution (which is the set of rules that his opponents are relying on). The analogy with Saint George and the Dragon defines the roles of the participants in this political battle: Băsescu cast himself and the public as a collective positive hero, while the opponents (the 322 MPs) are cast in the role of an enemy of Romania's institutional modernization and of the interests of the citizens. From the start, therefore, the conflict with his opponents is defined by the protagonist in a self-serving way, as a battle for or against modernization.

"A few days ago, 322 members of the Romanian Parliament voted in favour of suspending the President. The Romanian Parliament is a safeguard, ought to be a safeguard of your freedoms, of the prosperity of each Romanian, of the welfare of each Romanian. But we have one problem with these 322 members of parliament. Are they representing you in their vote? ([Crowd: 'No!!!]) What we have here is a manifestation of institutions of the state that do not take into consideration the will of the people. These people believe that the institutions of the state are at their service and they place them at their service and not at the service of the people. "

This paragraph is crucial to Băsescu's argument, as it introduces the challenge addressed to the 322 MPs that they do not in fact represent the will of the electorate. He claims (and the assembly agrees) that the fundamental rule of the democratic game, i.e. democratic representation, is violated: instead of representing the people, these MPs are serving their own interests. Implicitly, the 322 are illegitimate as they 
violate the rules of democracy and people's shared values and normative expectations (the first and second level in Beetham's definition).

"Let me explain... [Crowd: 'Traitors!' 'Traitors!'] No, they have only become detached from the interests of the people they claim to be representing. They are not traitors. They have only lost contact with the people that sent them into Parliament, these 322. Many of them may not even know why they voted as they did. This is what their bosses told them to do. They could tell them because they were not voted by each and every one of you. They were on a party list and, unfortunately, they are no longer on your list, on the list of the Romanian citizens. And our duty is to ask them to do their duty."

Interestingly, Băsescu refuses an option that is presented to him here by the audience, he refuses to call these MPs 'traitors' (he seems to view it as an ad hominem attack, therefore as an unacceptable move) and delegitimizes his opponent in a more reasonable way, in relation to premises that the audience already accepts: they are not 'traitors' but they have failed in the mission to faithfully represent the people who sent them into Parliament. The opponents' standpoint is delegitimized and discredited because the opponent is shown not to be playing by the publicly accepted rules of the democratic game. Băsescu also refers to a problematic aspect of the law itself: elections are on party lists, so that MPs are not elected directly by the citizens. He problematizes here the relation between the first level, that of the rules, and their justifiability in terms of shared beliefs, and conveys implicitly (through presupposition: 'unfortunately...') that there is a clash between the rules, as they are, and what they should be, according to people's expectations (again between the same two levels). The last assertion in the paragraph above is an interesting instance in which the immediate audience, but possibly also the Romanian people, as adjudicator, is included in a collective 'us' that includes the protagonist.

"In fact, what have I done to upset these 322 parliamentarians? I asked for high quality in the education system. Was I wrong in asking for this? [Crowd: 'No!!!] I wasn't wrong. I asked that the reform of the health system should be done for the people. Was I wrong? [Crowd: 'No!!!] I wasn't wrong. I have condemned the crimes of communism. Was I wrong? [Crowd: 'No!!!] I wasn't wrong. I have transferred the archives of the Securitate to the CNSAS so that nobody might be blackmailed in this country ever again. Was I wrong? [Crowd: 'No!!!] I wasn't wrong. (...) I have asked Parliament to introduce the uninominal vote in the next elections. Was I wrong? [Crowd: 'No!!!] I wasn't wrong. “

Băsescu is here eliciting from the interlocutor their agreement on premises whereby he progressively builds his own case. Upon being questioned, the audience agrees that it is not wrong to ask for various changes in the activity of various institutions. Băsescu seems in fact to be conducting an 'intersubjective identification procedure', whereby he is making explicit, actually constructing the level of shared beliefs in terms of which the audience is supposed to evaluate his standpoint.

"These are just a few of the reasons why, on the day of referendum, the vote you will have to cast for the impeachment of the President should be just one: 'No!' [Crowd: 'Băsescu! Băsescu!] These 322 Parliamentarians, and I repeat, 322 Parliamentarians, and not the Romanian Parliament, must receive one answer at the 
referendum: 'No'. The answer that shows that the President of Romania was not wrong to ask for the modernization of this country in favour of the Romanian people."

Here, the protagonist is making it clear that he has presented good reasons why the audience (and presumably the Romanians at large) should vote against the impeachment. There is an effective instance of strategic maneuvering at this point, with the help of dissociation: it is not the legitimacy of Parliament that Băsescu is contesting, but only that of the 322 MPs. He is thus making it clear that he is not contesting the principle of democratic representation but only a particular case in which its functioning was distorted. More interestingly, in this passage he is clearly expressing what is at stake in the confrontation. It is in fact a clash of values, norms, beliefs, between the supporters and the enemies of 'modernization'. Whoever will vote $N o$ will be on the side of those who advocate modernization in favour of the Romanians, based on the view that institutions should serve the people, not private interests.

"I would like you to know that I have an explanation for those who say that the President will not negotiate. What is there to negotiate? I would like to negotiate, but what? The ongoing lawsuits in the lawcourts? I can't negotiate them. What can I negotiate? The laws and government decisions whereby favours are granted to the political clientele? I can't negotiate those. What is there to negotiate? My peace of mind and my stability in office in order to be agreeable to the 322 by betraying my own electorate and the Romanian people? I could never do that. I'd rather fight openly with those who want another kind of Romania than the one you want."

Here, the protagonist orients explicitly to the conventions of another activity type, negotiation, only to reject the possibility of negotiating with his opponents: the matters under discussion are said to be non-negotiable. To negotiate would apparently contravene both the democratic rules of the game and widely shared norms and beliefs (it would be a 'betrayal'). This is, implicitly, because negotiation or compromise would mean that the interests of the opponents are also legitimate, albeit different from the interests of other Romanians. But their interests are not legitimate, they actually run against the interests of the people ('they want another kind of Romania', etc.) and this is why they cannot form the object of a negotiation.

Together with the possibility of negotiation, what seems to be rejected as well is the possibility of rational, critical discussion with the opponents. 'There is nothing to negotiate' means 'there is nothing to discuss', and this does not seem to be an unreasonable move in politics whenever there is no common basis for discussion in terms of shared beliefs and values. If the standpoint of the opponent is shut out from consideration here, it is because the opponent does not allegedly play by the rules of the democratic game (i.e. there is an inconsistency between what these MPs ought to be and what they actually are: they are 'representatives' that do not 'represent'). There is also a refusal of negotiation and dialogue on the grounds of the urgency of action, as opposed to discussion - again, a reasonable move in the political field, where public deliberation eventually has to give way to decision and to action, whether or not consensus on a matter has been achieved. The urgency of action is expressed in terms that the public could not disagree with, given their beliefs and value commitments, as the protagonist has constructed them up to this point: 
"We are not allowed to delay the transformation of the Romanian state until we can finally negotiate what can be done. We need a modern state now, a state where the money can reach the wretched peasant who has to do something with his wretched piece of land. Where the money can reach the villages... (...)The money must get to the people to spread prosperity to all and not only to the political clientele. This is a battle that we must all fight together."

Throughout these passages, the audience (and the adjudicator) is attributed the same values, concerns, needs and beliefs with Băsescu and is invited to join the protagonist in the battle for modernization.

"I was suspended with a total of 322 votes against one man. What the 322 members of Parliament did not understand was this: that they were not canceling the mandate of one man, but the vote of millions of Romanians. And this is unacceptable in a democracy. Practically, all of us are suspended citizens, suspended by 322 people. Who has given these 322 people the right to suspend our democracy?”

Băsescu claims here that the suspension of a democratically elected president is in contradiction with the rules of the democratic game (so, it is illegitimate from the point of view of the observance of democratic rules, the first level in Beetham's definition). To suspend a democratically elected President is, according to Băsescu, to cancel the votes of the people who elected him. From this, he moves on to the following equivalence: to suspend a president is to suspend the citizens who support him. Even more surprisingly, to suspend a democratically elected President is to suspend democracy itself (the principle of representation). These are examples of strategic maneuvering that gets badly derailed, strictly speaking, through false analogies. Most probably, however, these derailments went unnoticed for most of the audience and may have been quite effective in furthering Băsescu's case.

"Dear friends, (...) I come before you not as a representative of one party or another, or of any group. At the referendum I will stand before you as a representative of the Romanians... (...) My constitutional status means that I am a representative of the Romanians that has been called into question by 322 members of Parliament but is confronted with the vote of 22 million Romanians. I assure you that throughout this campaign I will act as a representative of the Romanians confronted with 322 members of Parliament."

But one thing has to be clear: nobody has given a mandate to these 322 members of Parliament to vote for the suspension of the President of Romania. They received their mandate from the oligarchs. And I am certain that any Romanian will vote against the oligarchs."

Băsescu is again thematizing his status as representative of the people, of all the Romanians, in a confrontation with the 322 MPs who represent private interests. He shows that he is legitimate by reference to both systems of rules, the Constitution and democracy: he was elected democratically and he submits himself again to a democratic vote. Again, he invokes representation as a fundamental rule and claims that the 322 MPs are illegitimate vis-a-vis this rule, as they have not received a mandate from them, but from private interest groups (the 'oligarchs'). More clearly than anywhere else, he asserts that the position of the people as adjudicator has to be against Băsescu's opponents, because the opponents' position is fundamentally that of 
the 'oligarchs'. In voting Yes, the Romanians would in fact support the interests of the 'oligarchs'. Unlike the 322 MPs, Băsescu claims to be fully representative of the will of the people: he is merely a spokesperson and a servant of the will of the people:

"Please rest assured that my mandate is one which I dedicate primarily to you, that it is a mandate which, for the first time, a President refuses to use for his own peace of mind, or as a mandate for the peace of institutions, for the peace of the oligarchs. I want this mandate to be devoted to you, even if this might lead to disputes, even if it might require the strength not to give in, and the obstinacy to serve the Romanians to the end."

A schematic reconstruction of Băsescu's argument might look as follows (in brackets, I indicate which particular level in Beetham's definition of legitimacy is drawn upon):

1. You should vote No in the referendum. (Claim).

1.1. The 322 MPs violate democratic rules (they do not represent the people but the 'oligarchs'). (L1)

1.1'. (We believe that) this is unacceptable in a democracy. (L2, L3)

1.2. The 322 MPs are against Romania's modernization.

1.2'. (We believe) that the time has come for Romania to become a modern state, a state where institutions work for citizens, etc. (L2)

1.3. I advocate institutional modernization.

1.3'. (We believe) it is not wrong/ the President was not wrong to ask for modernization of the education system, of the health system, of activity of government, etc. (L2, L3)

1.3”.We need a modern state now, we believe the money should reach the poor people, etc. (L2, L3)

1.4. I represent the Romanians (both according to the Constitution and according to the rules of democracy). (L1, as two distinct systems of rules)

1.4' (We believe in the legitimacy of the Constitution.)

1.4” We believe in democratic representation. (L2, L3)

Premise 1.2a, for example, is supported by invoking people's beliefs (L2), but also by eliciting the audience's consent (L3) by means of direct questions: 'Was it wrong for me to ask for $\mathrm{x}, \mathrm{y}, \mathrm{z}$ ?', to which the audience replies: 'No!'. Shared beliefs (Beetham's second level) are invoked either to support the protagonist's position (1.3, 1.4) or to indicate that there is a clash with the opponents' position $(1.1,1.2)$ : shared beliefs contravene the way in which the opponents are playing the political game.

What is most interesting about this argument is the way in which the difference of opinion over whether Băsescu should be impeached is redefined by the protagonist as one over whether Romania should become a modern democratic state: according to the protagonist, to vote Yes is to vote against modernization and against democracy. It can be argued that the topic of 'modernization', as a fairly abstract, meta-level reflection on the state of affairs in Romania, ran the risk of appearing 
irrelevant to the discussion, and its justificatory potential to the claim defended may have not been immediately obvious to parts of the audience. The protagonist, however, elicited sufficient agreement from the audience that the 322 MPs were acting against the interests of modernization and democracy, and that, moreover, what people believed and wanted was practically tantamount to a modern democratic state, for this instance of strategic maneuvering at the confrontation stage to appear perfectly reasonable.

Another interesting example of strategic maneuvering (this time, at the opening stage) which draws on the conventions of the adjudication as activity type is the way in which the protagonist redefines premises that are accepted as mutual concessions into propositions that serve his own rhetorical objectives, while preserving the compatibility of these revised propositions with the original concessions. Starting from the same set of shared premises at the opening stage (a mutual recognition of the President's over-active involvement in various domains), the two parties can be seen as moving in opposite directions, arguing for different claims or interpretations of the facts. More precisely, drawing on these shared premises, together with an interpretation of these that is not favourable to Băsescu, plus reference to a legal background, Băsescu's opponents claim that the President is not legitimate because he has not obeyed the rules of the Constitutional game which the population also allegedly adheres to. For his part, drawing on the same shared premises, on another type of normative background (democracy), and on a selfserving interpretation of the mutual concessions, Băsescu constructs an argument of legitimation for himself. His position is allegedly legitimate because he has consistently played by the rules of the democratic game, whose fundamental principle is representation of the interests of the people, and this is a set of rules that the population allegedly widely supports. ${ }^{3}$

In what way is this adjudication different from the typical adjudications going on in the legal field? In principle, the adjudicator is or should be neutral and cannot be enlisted by either party in support of their cause. Thus, it is striking to observe how Băsescu claims commonality of values, goals etc. with the adjudicator on matters which are strictly relevant to the success of his case ('I am certain that every Romanian will vote against the oligarchs'). Because he and the adjudicator are allegedly committed to the same values, it can only follow that, when presented with the facts, the adjudicator can only decide in Băsescu's favour. This peculiarity arises from the particular kind of political game Băsescu is engaged in, and from the particularities of the political field in an electoral situation, where the adjudicator is the people, and each party or politicians supposedly represents the interests of the people as ultimate adjudicator. To enlist the adjudicator on your side and invest it with a commitment to the values, goals, etc. that you stand for, is therefore presumably not an unreasonable move in the political field, but may have to do with the logic or principles of the political field, as I will suggest below.

To conclude, a form of adjudication is what is apparently going on and those involved conspire in creating that appearance (by apparently asking for and offering judgment). But adjudication is in a sense not what is going on. The adjudicator seems to be here less of an impartial judge than a construct of the protagonist's own making. This is because the adjudicator is not merely the electorate, as an aggregate of different views and options, but a more unitary entity, the people, a construct endowed by the protagonist with all the commitments to those values and beliefs that will help forward his own case. So, in apparently asking for the people's objective judgment, the protagonist is in fact presenting a case defined in terms that will serve 
his rhetorical objectives to a judge whom he has discursively constructed as sharing exactly those commitments that will argue for his case.

\section{The contradictory logic of the social and political fields}

The French sociologist Pierre Bourdieu (1991) analyzes the political field as a site par excellence in which words are actions and the symbolic character of power is at stake. It is a field of forces and of struggles aimed at transforming the relation of forces which confers on this field its structure at any given moment. Agents in the political field are continuously engaged in a labour of representation by which they seek to construct and impose a particular vision of the social world (i.e. a particular ideology, or 'truth'), while at the same time seeking to mobilize the support of those upon whom their power ultimately depends. These visions cannot be assessed independently of their power of mobilization. 'Thus, the production of ideas about the social world is always in fact subordinated to the logic of the conquest of power, which is the logic of the mobilization of the greatest number'. Politicians, in other words, have to produce 'ideas that are capable of producing groups' (Bourdieu 1991: 181-182). The underlying logic of the political, as Bourdieu understands it, has to do with mobilization, i.e. with power, not primarily with truth. Politicians can obtain power if their ideas are recognized by a majority, if they can mobilize a higher number than their political competitors. The power of a discourse 'depends less on its intrinsic properties than on the mobilizing power it exercises - that is, at least to some extent, on the degree to which it is recognized by a numerous and powerful group' (Bourdieu 1991: 188). And one issue to speculate on is to what extent this particular logic affects the boundaries of reasonableness in the political field.

Bourdieu speaks of the political 'game' as a 'double game' (Bourdieu 1991: 180-183), in which the 'external' relation of politicians to the electorate is subordinated to the 'internal' struggle for power within the political system. There is 'duality of frames of reference': the politician is simultaneously playing a game in the political field, against his competitors, and a game in the social field, in which he represents his electorate. There is a 'homology' between these frames of reference, such that politicians 'serve the interests of others in so far (and only in so far) as they also serve themselves while serving others' (Bourdieu 1991: 183). In other words, a successful move in one game is also a successful move in the other game. Or, if a politician allows himself to be discredited by a political opponent, he is at the same time doing a disservice to his own electorate.

The game of representation of the views and interests of the electorate typically takes the form of a game of democratic representation, in which politicians claim to represent the interests of the entire population or of large sections, as power depends on successful mobilization of majorities. In terms of the analysis undertaken here, we can say that Băsescu is playing an (external) game of 'democratic representation' (he is an alleged spokesperson, giving voice to the vision of the public, he knows 'what kind of Romania' the public wants) and an (internal) 'power game' within the political field against his competitors. He can win the game against his political adversaries if he plays the game of democratic representation in such a way as to gain the adherence of the highest number of people. The way in which he has to play this latter game is thus subordinated to the imperative of mobilization, as it is the power to mobilize that gives politicians their power in relation to their competitors. 
In any society there will always be disagreement that is irreducible. Yet, there is a need for decision and action and for an end to disagreement. The basic idea behind the democratic conception of legitimate authority is that when there are disagreements, more exactly when public deliberation fails to deliver a consensus on the common good, the way forward is by means of a decision-making process that is fair to the views and interests of all members, in the only way in which it can possibly be fair, by submitting issues to a democratic vote and deciding that one will defer to the decision of the majority (Christiano 2004). In other words, disagreements over substantive conceptions of what social arrangements should be are overridden by a fundamental agreement on the legitimacy of democratic procedure.

In his speech, Băsescu is very insistent on the theme of democratic representation and he makes it appear straightforward and unproblematic: the representative speaks in the name of the people and expresses the people's wishes, the people give a mandate of representation to politicians in order to make their voices heard and can withdraw this mandate when politicians do not express and serve their interests. There is also a repeated insistence on the idea of modernization and on the construction of a consensus around this idea. Yet, modernization is the only substantive topic on which consensus is invoked, and, as the dialogue with the audience shows, readily obtained. Most of the speech focuses on the idea of democratic representation, which is a procedure, a principle. Why is the protagonist drawing so heavily on democratic representation as a topical choice? Is this topic suggested perhaps by the properties of the political field?

Băsescu seems to know that, if he can convincingly show that his opponents are violating the democratic game, while he is playing fairly by the rules of this game, he will succeed in mobilizing a large part of the electorate. This is because, on a variety of substantive issues, the electorate will be predictably divided. There is no point in raising potentially controversial substantive issues, unless one can be certain that there is consensus on that issue (e.g. the desirability of modernization). However, as Băsescu knows, there is a wide consensus on the desirability of democratic processes. This is the one consensus that it is therefore strategically advisable to draw on and to identify one's own position with.

According to Bourdieu, however, the situation is much more complex than it appears. The political field involves a paradox: individuals cannot constitute themselves as a group with a voice, capable of making themselves heard in the political field unless they dispossess themselves in favour of a spokesperson in whom they vest the right to speak on their behalf. There is a 'monopoly of the professionals' that goes hand in hand with this 'dispossession', or 'delegation' of power from the people to the politician. In all these cases of dispossession, Bourdieu argues, 'in appearance the group creates the man who speaks in its place and in its name ... whereas in reality it is more or less just as true to say that it is the spokesperson who creates the group' (Bourdieu 1991: 204). Thus, instead of a politician expressing the interests of the group, what we have in fact is a politician postulating group-interests that favour his own position in the political field.

Bourdieu also speaks about a so-called 'oracle effect': 'the fact of speaking for someone, that is, on behalf of and in the name of someone, implies the propensity to speak in that person's place'. Thus, the spokesperson is speaking 'in the name of something which he brings into existence by his very discourse', 'producing both the message and the interpretation of the message', while giving the illusion of being just a 'symbolic substitute' (Bourdieu 1991: 209 -212). It is in apparently abolishing his own voice and identity completely, in becoming a representative of the people, that 
the politician appropriates the power of the people. And in allegedly acting as a spokesperson, the politician can invent the people's message according to his own interests. This is arguably what Băsescu is doing here with the topic of 'modernization' - definitely, not a message extracted from the people, but a topical choice of his own invention, which is only attributed to the people, as an alleged shared concern, yet a very effective choice in the game of mobilization of majorities.

These aspects of the logic of the political field are best kept away from the public, as this particular speech shows. The protagonist has to conceal from the public the extent to which the game of democratic representation is in fact a power game, a game in which he is not surrendering his power to the power of the people (submitting himself to the people as adjudicator, etc.) but appropriating its power, enlisting the adjudicator on his side. It is quite significant, I think, that, in referring to his adversaries, he is representing them as enemies of democracy and of the people. In other words, he only places them in the external game, in which they should, but allegedly fail to represent the people, and not in the internal game of power in which he competes with them. In other words, in order not lose the power game, politicians must give visibility to concerns with the democratic game as a game of transparent, faithful representation, and conceal other considerations of power as far as possible.

As Bourdieu observes, regardless of their divergent interests and aims, all participants in the struggles of a field will share certain fundamental presuppositions. All participants must believe in the game they are playing and in the value of what is at stake. There is therefore a fundamental complicity underlying all antagonisms. There seems indeed to be a limit on how far Băsescu can go in his critical evaluation of how the democratic game is actually played. He must effectively delegitimize his adversaries, but be careful not to delegitimize the game itself, and the idea of democratic representation, as this will demobilize the electorate. He is not allowed to be cynical, he must not question the belief that democratic representation is in fact perfectly possible. He must not endanger the idea that politics involves a collective search for 'truth' through public deliberation, and that the voices of the public can indeed make themselves heard. The outcome he must avoid at all costs is one in which the population, already disgusted with the corruption of the political class, might refuse to continue to play the game, might refuse, for instance, to show up to vote in the referendum. He is in fact quite careful to instil a sense of civic duty and commitment in the audience ('it is our duty to make them do their duty'), as he knows that his fate in the internal power game depends vitally on the capacities for mobilization he can command.

From the point of view of my discussion of legitimacy, it is significant that the two 'games', while being equally real, are not equally legitimate in the eyes of the public. People may accept and understand that politics is also about power, and that it couldn't be otherwise, but more often than not regard this as cynicism on the part of politicians, which can lead to cynicism on their part towards politicians. So politicians cannot legitimize themselves before the public in terms of how well they observe the rules of the game of power, but only in terms of how well they observe the rules of the democratic game. Politicians know that they can lose the power game if they are not seen to play the democratic game well enough or if they are seen to be concerned only with personal power: the internal game does not mobilize, but the external one does.

The contradictory nature of the social and political fields manifests itself in a diversity of judgements of what is legitimate in politics and political discourse. Judgments made by 'insiders' of the political game will tend to differ from those of 
the public. And again such judgments will vary depending on the political, ideological position that one is speaking from. These contradictions arise from the absence of consensus on substantive issues: a variety of ideologies, visions, truths, vie for recognition by as many people as possible. Not one consensus, but a multiplicity of agreements are created by politicians around particular visions, particular 'truths'. Although the democratic game claims to be geared to consensus, to the resolution of differences of opinion by public deliberation, there are inherent limits placed on this game, arising from the need to mobilize majorities so as to be able to serve particular power interests and engage in collective action.

\section{Conclusion. Strategic maneuvering as managing the internal contradictions of the political and social fields}

So, what does all of the above tell us about how politicians ought to conduct arguments of legitimation that are acceptable to a reasonable critic? A neat hypothesis, which has the advantage of preserving a parallelism with the distinction between 'rhetorical' and 'dialectical' objectives (van Eemeren and Houtlosser 2002), is that politicians stay within the bounds of reasonableness and of legitimacy as long as they strategically maneuver successfully between the constraints of the democratic game and those of the power game, i.e. without allowing either game to undermine the other. So, strategic maneuvering in the political field could be seen as trying to manage a double orientation: an orientation towards the democratic ideal or normative vision, at the same time with an orientation to power through mobilization of the highest number of voters. This view might suggest that the two games are pulling in opposite directions, but this needn't be the case. In fact, the more convincing the case you can make for yourself as a representative of the will of people, and the better you can voice the views and interests of your electorate, the higher the number of supporters you will probably mobilize. This is probably because the democratic game is always geared to a partial vision and to certain well-defined interests. It is not a game of 'truth' through critical discussion, although it claims to be that. Only if we conceived of the democratic game as a game of the collective search for truth in politics, through deliberation that is ideally free and equal, would it be conceivable that a politician might lose the power game if he played the democratic game too well, i.e. too critically, too openly. For instance, should he allow the public to see through the 'double game', or to glimpse the multiplicity of relative, partial 'truths' and the way they feed particular power interests, he might then risk losing the adherence of the electorate. Or should he allow debate on matters of policy that are claimed to be in the general interests to go on indefinitely in a free critical discussion, people might discover that was allegedly in the general interest is not in fact in the general interest, but serves the interests of one or another party. But the democratic game is not played in this way, but is always attached to some existing consensus on one 'truth' or another and to some particular power position.

Because politicians aim to mobilize majorities, they will have to adapt their message to a heterogenous public, made up of 'reasonable' and 'unreasonable' critics. Some will be easier to persuade than others, even when no good reasons are provided, but even the most reasonable critics might not ultimately penalize unreasonable argumentative behaviour by withdrawing their consent, but will think first of the wider power objectives that they pursue in supporting a politician. Social actors in the social and political field are themselves not free from personal interests and cognitive 
biases. On the contrary, in supporting a politician, they are pursuing their own interests and embracing various political visions or 'truths' which may be different from those of others. From their own situated perspectives, from which they cannot easily step back, they are likely to view certain argumentative maneuvers with a critical eye or to completely overlook moves which other actors may consider unacceptable. Because of the logic of the field, as a field of forces and struggles for power, even 'reasonable critics' may behave like pragmatists and adopt a rhetorical perspective on reasonableness: anything that works with the electorate and obtains more votes for our candidate, by any means, is reasonable, given that the ends pursued are considered legitimate. This is how parts of the Romanian electorate probably reasoned in the 2004 elections, when Băsescu was massively supported by everyone who identified himself with the battle against corruption, and most prominently by Romania's leading critical intellectuals. The overlapping consensus that Băsescu exploited and benefited from at the time consisted mainly in the population's attitude towards the corruption of the political class. By contrast, when dealing with political adversaries, the reasonable critic might adopt a less lenient perspective and to penalize unreasonable moves and show how they are geared exclusively to power interest or to illegitimate political visions. This is presumably because judgments of reasonableness in politics, like judgements of legitimacy, tend to be made from the perspective of a situated social and political position, from a particular set of values, beliefs, norms, goals, from the perspective of a particular truth.

In addition, because of the 'homology' that Bourdieu speaks of between the political field and the fields in which a politician's supporters are playing, and which are affected by the outcome of the political battle, behind the electorate's massive support for Băsescu there also seemed to lie the realization that, in the Romanian context, a politician that behaved differently, that did not do precisely those things which the critical intellectuals would have otherwise been critical of, would not after all, in a sense, behave reasonably, politically speaking. Băsescu would not have served the interests of his electorate well if he had behaved in a way which would have lost him votes or would have placed him at a disadvantage vis-à-vis his competitors in the political field. So, a definition of reasonableness in the political field will probably have to incorporate the notion of power and of serving the interests of the electorate one represents, in the process of fighting your opponents. And this is my first point in trying to move towards a conclusion.

But there clearly has to be more to judgments of reasonableness and legitimacy than the way they serve power positions from particular perspectives. And this is the second point I am suggesting towards a conclusion and it is inspired by Scott Jacobs's (2002) discussion of the contextual nature of fallacies, as it seems to account very well for the reception of Băsescu's discourse since 2004. The fact is that Băsescu's frequently unreasonable argumentative moves (part of what I have analyzed elsewhere as a radical version of populism - Ieţcu 2006, Ieţcu-Fairclough 2007, Ieţcu-Fairclough in press) have been constantly welcomed, not criticized, in Romania, as being well-adjusted to the Romanian electorate, which they have seen in terms of a predominantly parochial and dependent political culture and inertial, traditionalist political options. In such contexts, as Jacobs suggests, moves which may otherwise be judged fallacious may actually constitute constructive contributions to the public debate, place people a better position to decide what to do, who to vote for. In other words, reasonable argumentation can be viewed, following Jacobs, as argumentation that adjusts to the practical demands of the situation, that makes the best of a less-than-ideal situation, and of an audience which does not approximate the 
'reasonable critic' except maybe to an insignificant degree. This view does not collapse into a rhetorical view. Reasonable argumentation will be that argumentation which, given what the situation is, and what the available alternatives are, will not merely take advantage of the situation (of the ignorance and gullibility of the public) but will try to improve the conditions for deliberation, create a space for reflection on different views, help people move a little closer to being reasonable critics or rational judges, and thus enable them to come to a better informed decision. One can argue of course that this is not what the majority of Băsescu's supporters saw and valued in him at the time, but this could provide a criterion for evaluating argumentation that incorporates facts about the context and its limitations. And it can also be argued that some of Băsescu's attempts at self-legitimation during the 2004 campaign did contribute to improving the conditions of deliberation in precisely the sense above. So, my second concluding point would be that judgments of reasonableness and of legitimacy in the political field, should be placed in concrete political, social contexts, and assessed in terms of the shared beliefs and norms of a given community and in terms of how they attempt to transform these contexts.

Thirdly, it would seem that we cannot define the specific character of reasonable or fallacious argumentation for the political field and the activity types associated with the various games played within it, as such. Judgements of what is reasonable vary, as I have indicated, according to the positions people occupy in the political practice, as 'insiders' to the political game or as 'outsiders', as supporters or opponents of particular politicians or ideological positions. If one draws on Bourdieu, one will tend towards a sociological view which focuses on what people in various social fields and social practices take to be reasonable argumentation. The view suggested by Beetham is also a sociologist's perspective, a view of legitimacy-incontext. So I would like to conclude by posing a question: as pragma-dialectics moves towards a concern with differences between social fields, social practices, and activity types with respect to reasonableness and fallacies, in what way can the differences and the relationships between judgements of reasonableness on the part of participants in specific social practices and on the part of critical analysts - or between practical and theoretical judgements of reasonableness - be given further consideration? And more specifically, what might a sociological perspective have to say about philosophical, theoretical and critical conceptions of reason and reasonableness that might enrich the pragma-dialectical view? 


\section{References}

Beetham, David (1991) The Legitimation of Power, London: MacMillan.

Bourdieu, Pierre (1991) Language and Symbolic Power, Cambridge: Polity Press.

Christiano, Tom, "Authority", The Stanford Encyclopedia of Philosophy (Fall 2004 Edition), Edward N. Zalta (ed.), http://plato.stanford.edu/archives/fall2004/entries/authority/>.

D'Agostino, Fred, "Public Justification", The Stanford Encyclopedia of Philosophy (Spring 2007 Ed.), Edward N. Zalta (ed.), http://plato.stanford.edu/archives/spr2007/entries/justification-public/>.

Eemeren, Frans H. van \& Rob Grootendorst (1992) Argumentation, Communication and Fallacies. Hillsdale, NJ: Lawrence Erlbaum Associates.

Eemeren, Frans H. van \& Rob Grootendorst (2004) A Systematic Theory of Argumentation. The pragma-dialectical approach, Cambridge: Cambridge

University Press.

Eemeren, Frans H. van \& Peter Houtlosser (2002) Strategic Maneuvering: Maintaining a Delicate Balance. In: F. H. van Eemeren and P. Houtlosser (eds.) Dialectic and Rhetoric. The Warp and Woof of Argumentation Analysis, Dordrecht: Kluwer Academic Publishers.

Eemeren, Frans H. van \& Peter Houtlosser (2005) 'Theoretical construction and argumentative reality. An analytic model of critical discussion and conventionalized types of argumentative activity', in D. Hitchcock \& D. Farr (eds.) The Uses of Argument. Proceedings of a Conference at McMaster University, 18-21 May, 2005.

Eemeren, Frans H. van (2006) 'Coming to Grips with Strategic Maneuvering in Argumentative Discourse', keynote address at the Eleventh Biennal Wake Forest Argumentation Conference, Florida Atlantic University, February 1618, 2006.

Eemeren, Frans H. van \& P. Houtlosser (2007) 'Coming to Grips with Argumentative Discourse', in Hans V. Hansen \& Robert C. Pinto (eds.) Reason Reclaimed, Newport News, VA: Vale Press.

Habermas, Jürgen (1976) Legitimation Crisis, London: Heinemann.

Habermas, Jürgen (1984) The Theory of Communicative Action. Volume One. Reason and the Rationalization of Society, London: Heinemann.

Habermas, Jürgen (1996a) 'Legitimation Problems in the Modern State', in Outhwaite, William (ed.) (1996) The Habermas Reader, Cambridge: Polity Press.

Ieţcu, Isabela (2006) Discourse Analysis and Argumentation Theory: Analytical Framework and Applications. Bucureşti: Editura Universităţii din Bucureşti.

Ieţcu-Fairclough, Isabela (2007) 'Populism and the Romanian Orange Revolution: a discourse-analytical perspective on the presidential election of December 2004', Studies in Language and Capitalism, 2(1): 31-74. 
Ieţcu-Fairclough, Isabela (in press) 'Branding and strategic maneuvering in the Romanian presidential election of 2004. A critical discourse-analytical and pragma-dialectical perspective', Journal of Language and Politics.

Jacobs, Scott (2002) 'Messages, Functional Contexts, and Categories of Fallacy: Some Dialectical and Rhetorical Considerations', in: F. H. van Eemeren \& P. Houtlosser (eds.) Dialectic and Rhetoric. The Warp and Woof of Argumentation Analysis, Dordrecht: Kluwer Academic Publishers.

\footnotetext{
${ }^{1}$ The disadvantages of a purely descriptive view are immediately obvious. Belief in the legitimacy of power can be achieved in various ways, including through ideological propaganda, and people may have reasons for believing that power is legitimate which have nothing to do with the qualities of the system. In addition, it is not in fact even necessary for belief in the legitimacy of a power regime to prevail among a majority of a population in order for that regime to survive unchallenged. It is sufficient for such beliefs to exist among the relevant power elites; most other people will go along with a system of power either through coercion, following perceptions of their own powerlessness or of the ways in which an illegitimate power system serves their own interests, or other reasons which may not involve belief in legitimacy. Furthermore, as Beetham (1991) observes, the view of legitimacy as belief in legitimacy has the unwanted consequence that a totalitarian system of power might be considered legitimate as long as it successfully managed to indoctrinate a sufficient number of the population into believing that it is legitimate.
}

${ }^{2}$ Problems with normative approaches have been pointed out. One refers to the very possibility of consensus. For some theorists, the search for consensus involves an attempt at universalization, a 'reduction to consensus', which tries to level off irreducible differences which should be given recognition instead (Christiano 2004). It is nevertheless possible to preserve the notion of reasonable consensus by viewing it, as Rawls does, as an overlapping consensus. Citizens, that is, do not have to agree on everything but only on those principles that apply to the basic structure of society. A normative approach also seems to presuppose a unique interpretation of what it is reasonable to believe and desire with respect to social and political arrangements. But, if there is reasonable disagreement about the demands of reason itself, i.e., if there are different conceptions of reasonableness, then groups within a community may have different understandings of what is publicly justified within that community, and hence different notions of what institutions might be legitimate for that community (D’Agostino 2007).

${ }^{3}$ Băsescu's partially implicit argument can be said to go as follows: 
1.1. I have become involved in the activity of the law, government, secret services, Parliament, education, health etc.

1.1.' This involvement is equal to an attempt to modernize Romania, place institutions in the service of the people, etc.

1.1'.1. The people believe that institutions should represent their interests, that Romania ought to become a modern state, etc. (Beetham's second level, of shared beliefs)

1.1'.2. My actions have obeyed the rules of the democratic political game (i.e. representation, etc.) (Betham's first level, of rules)

1. Therefore, my position is legitimate.

His opponents' argument is the following:

2.1. Băsescu has become involved in the activity of the law, government, secret services, Parliament, education, health etc.

2.1'. Being thus involved is tantamount to a violation of legitimate prerogatives granted by the Constitution.

2.1'.1. The people believe that the Constitution should be respected.

2.1'.2. The President is not observing the Constitution.

2. Therefore, Băsescu's position is not legitimate. 